\title{
The Beveridge Curve in Europe: New evidence using national and regional data
}

\author{
Florence Bouvet *
}

March 2009

\begin{abstract}
In this paper, national and regional data on job vacancies and unemployment are combined to estimate the Beveridge curves of five European countries and 60 regions, focusing on the period 1975-2004. The Beveridge curve depicts the empirical negative relationship between job vacancy rate and unemployment rate, and reflects the efficiency of the job matching process. Movements along a fixed downward-sloping Beveridge curve are associated with cyclical shocks, while shifts of the curve arise from structural factors that alter the matching efficiency between job vacancies and unemployed workers. With the same data I then analyze shifts in the Beveridge curves and determine whether these shifts are due to structural changes affecting the matching efficiency, or to cyclical factors. The empirical evidence suggests that changes in labor market institutions, longterm unemployment, as well as cyclical shocks are responsible for outward shifts in European Beveridge curves.
\end{abstract}

- Keywords: Beveridge curve, unemployment rate, European Union

- JEL Codes: E24, E32, R10

*Address: Department of Economics, Sonoma State University, 1801 E. Cotati Avenue, Rohnert Park, CA 94928, email: bouvet@sonoma.edu 


\section{Introduction}

To study the dynamics of aggregate labor market, macroeconomists have used two empirical relationships: the Philips curve and the Beveridge curve. The Beveridge curve captures the empirical inverse relationship between the unemployment rate and the vacancy rate. The starting point for deriving the Beveridge curve is a matching function between unemployed workers and vacant jobs. Generally, movements along a fixed Beveridge curve have been associated with cyclical factors, while shifts in the Beveridge curve (i.e. higher or lower unemployment rate for a given vacancy rate) have been interpreted as reflecting structural changes which affect the matching between jobs and unemployed workers.

In their 1989 paper (Blanchard et al., 1989), Olivier Blanchard and Peter Diamond argued that, until then, the importance and usefulness of the Beveridge curve had been underestimated by macroeconomists. Yet, the level and persistence of unemployment in Europe in the 1980s revived interests in the Beveridge curve. Blanchard and Diamond's article was indeed followed by the publication of numerous empirical papers that either estimate the matching function (Blanchard et al., 1989; Petrongolo and Pissarides, 2001; Coles and Smith, 1996; Gorter et al., 1997; Gorter and van Ours, 1994), or study the stability of the Beveridge curve and the reasons behind its shifts (see for instance Valletta (2005) for the USA, Börsch-Supan (1991) for German Länder and Wall and Zoega (2002) for British regions).

While the vast majority of the papers on the Beveridge curve focus on one country and/or its regions, the analysis presented below provides a comparative analysis of the Beveridge curve in several countries and their regions. This paper indeed provides estimates of the Beveridge curves for five European countries (Belgium, Germany, the Netherlands, Spain and the UK) and their 60 regions, focusing on the period 1975-2004. Thus, this paper updates the findings of work done using less recent data (Börsch-Supan, 1991; Wall and Zoega, 2002). I also examine shifts in these curves and whether these shifts are due to structural changes affecting the efficiency of the matching between jobs and unemployed workers, or to cyclical factors. I consider the effects of long-term unemployment and institutions that could introduce 
rigidities in the labor market. Business cycles are captured with a measure of the output gap, while productivity growth, regional dispersion of employment, and sectoral shifts control for additional economic structural shocks.

The remainder of the paper is organized as follows. The Beveridge curve is derived in Section 2. Then Section 3 presents and compares the Beveridge curves of the aforementioned five EU countries and their regions. In Section 4, I estimate both national and regional Beveridge curves, and look at possible factors, structural and cyclical, responsible for the shifts observed in Section 3. Section 5 concludes.

\section{Derivation of the Beveridge curve}

What underlies the negative relationship between vacancy rates and unemployment rates? The starting point for deriving the Beveridge curve proposed notably by Blanchard et al. (1989) and Pissarides (2000) is a matching function between unemployed workers and firms ${ }^{1}$. The matching-function gives how many successful matches $(M)$ of unemployed workers $(U)$ and firms with vacancies $(V)$ occur every period:

$$
M=M(U, V)
$$

$(M(U, V))$ is an increasing function in both the number of unemployed and the number of vacancies. Moreover, the matching function exhibits the following property: $M(U, 0)=$ $M(0, V)=0$. The matching function captures the idea that there is uncoordinated, costly and time-consuming trade in the labor market, and thus summarizes the effectiveness of the technology that pair unemployed workers with firms searching for employees.

In their extensive survey of the matching function, Petrongolo and Pissarides (2001) find that most empirical analyses specify the matching function as Cobb-Douglas and provide evidence of constant returns to scale. We can therefore express equation 1 as:

\footnotetext{
${ }^{1}$ See Petrongolo and Pissarides (2001) for an overview of the matching function literature and its relation to the Beveridge curve.
} 


$$
M=A U^{\gamma} V^{1-\gamma}
$$

The term $A$ captures the matching efficiency and the idea that the position of the Beveridge curve in the $U-V$ space might change over time. Scaling both sides of equation 1 by the labor force, the hiring rate $(m=M / L)$ can be expressed as a function of the unemployment rate $(u=U / L)$ and the vacancy rate $(v=V / L)$ :

$$
m=A u^{\gamma} v^{1-\gamma}
$$

In the labor market steady state, a constant unemployment rate implies that the matching rate equals a fixed separation rate $(s)$. Equation 3 can be rewritten as:

$$
u=\left(\frac{s}{A v^{1-\gamma}}\right)^{\frac{1}{\gamma}}
$$

Thus, for a constant separation rate, equation 4 implies the existence of a negative relationship between the unemployment rate and the vacancy rate in steady state (figure $1^{2}$.

-Figure 1 here-

In steady state, movements along a fixed downward-sloping Beveridge curve are associated with cyclical shocks, while shifts of the curve (i.e. positive co-movements of the unemployment and vacancy rates) arise from structural factors that alter the matching efficiency (Bowden, 1980; Petrongolo and Pissarides, 2001). An upward movement along the Beveridge curve is typical of a negative shock to aggregate demand: fewer jobs are available (fewer vacancies) and jobs are harder to find (higher unemployment rate). Outward shifts imply a reduction in the matching efficiency, and thus a deterioration of the labor market. These shifts can notably be due to characteristics of the unemployed, changes in search effort and search effectiveness

\footnotetext{
${ }^{2}$ While the Beveridge is usually plotted with the vacancy rate on the vertical axis, I chose to plot the unemployment on the vertical axis to be consistent with equation unempl-equation and the empirical analysis conducted in Section 4.
} 
that can be affected by the generosity of the unemployment insurance system (Jackman et

al., 1989), and other labor market policies (Jackman et al., 1990; Bowden, 1980). An upward ward movement along the Beveridge curve can also induce an outward shift of the curve. This hysteresis effect is caused by long spells of unemployment which make unemployed workers less likely to find employment due to human capital deterioration or the negative perception by employers (Røed, 1997; Blanchard and Summers, 1987; Pissarides, 1992; Blanchard and Diamond, 1994).

\section{National and regional Beveridge curves in Europe}

The sample is composed of 60 NUTS I or II regions (Nomenclature of Territorial Units for Statistics) for the five following EU countries: Belgium (3 regions), Germany (16 regions), the Netherlands (12 regions), Spain (18 regions) and the UK (11 regions).

Figure 2 presents the empirical relation between the national unemployment and vacancy rates for the five countries studied in this paper. While the Beveridge curve is usually drawn with the unemployment rate on the horizontal axis and the vacancy rate on the vertical axis, I have inverted the axes in the graphs presented below to match Equation 4 and the empirical analysis presented in Section 4 where the unemployment rate is used as the dependent variable.

Both unemployment rates and job vacancies data are obtained from the OECD Registered Unemployment and Job Vacancies dataset which is a subset of the Main Economic Indicator (MEI) database. Job vacancies data refer to the stocks of unfilled job vacancies. The resulting plots suggest significant changes in the matching efficiency over the past three decades.

All of the five countries have experienced movements along a stable Beveridge curve between 1979 and the mid-1980s, followed by an outward shift during the second half of the 1980s. Moreover, during this first period (1975 to 1984), the Spanish and Belgian Beveridge curves were almost vertical. Between 1984 and the early 1990s, the Beveridge curves of the UK, Spain, the Netherlands and Belgium exhibit the expected clockwise adjustment pattern (rise in the unemployment rate contemporary to a fall in the vacancy rate) around recessions 
(1981-1982 and 1992-1993). Afterwards, the experience of Germany differs from the other four countries. While the Netherlands, the UK, Spain, and, to a lesser extent, Belgium have experienced improvements in the matching efficiency (inward shifts), the labor market kept deteriorating in Germany. Nickell and van Ours (2000) attribute the reduction in unemployment in the Netherlands and the UK to changes in the unemployment benefit systems that became less generous, an increase in the proportion of part-time workers which increased female labor force participation in both countries. In the case of Spain, improvements in the labor market were triggered by the country's accession to the EU which notably pushed the Spanish government to liberalize fixed-term labor contracts. Consequently, the employment gains that Spain experienced in the 1990s were driven by the increase in temporary job contracts. The continuing outward shifting of the German Beveridge curve can be attributed to the impact of the reunification on the aggregate labor market (Börsch-Supan, 1991). Finally, in the early 2000s, Germany is still the only country where the labor market kept deteriorating. While the Spanish Beveridge curve became flat, the Beveridge curves in the UK, Belgium and the Netherlands shifted inwards. This inward shift was also observed in the USA (Valletta, 2005).

-Figure 2 here-

Moving to the regional level, regional Beveridge curves are presented in figures 3 to 7 . Data on regional unemployment rates are from the Eurostat Regio data set, while I obtained regional unfilled vacancy data from several sources. For Spain, regional data were kindly provided by Pablo Antolín (see Antolín (1994)). For the UK, vacancies data are the stocks of vacancies notified to Jobcentres (up to 2001). This dataset can be found online on the Office for National Statistics website (http://www.statistics.gov.uk). Regional data for Belgium are available from Belgostat, while data for the Netherlands were obtained from the national statistical institute, Statistics Netherlands (http://www.cbs.nl). Data for German Länder were collected from regional statistical institutes (see http://www.statistik-portal.de/ Statistik-Portal/en/en_LinksUebersicht.asp).

Most Western Länder in Germany have experienced the same shifts as the aggregate Bev- 
eridge curve for Germany. Similarities between the national and regional curves can also be observed for Spain where several curves are vertical until the mid-1980s and shift inward after 1999. As for the UK, most regional plots exhibit two relatively stable curves: one during the 1980s and then an inward shift.

-Figure 3 here-

-Figure 4 here-

-Figure 5 here-

-Figure 6 here-

-Figure 7 here-

In the next section, I examine the possible reasons behind these shifts.

\section{Why do European Beveridge curves shift?}

In this section, I discuss possible explanations for the shifts of national and regional Beveridge curves described in the previous section. Four groups of factors could explain the observed shifts: composition of the unemployed population and the labor force, institutional factors affecting the matching efficiency between unemployed workers and job vacancies, business cycle, and other structural shocks such as productivity growth and reallocation of employment across sectors and regions.

The first hypothesis tested is that shifts in the Beveridge curve can be explained by changes in the composition of the pool of unemployed (Börsch-Supan, 1991; Wall and Zoega, 2002), as this might affect job search efficiency. I control for the importance of women and long-term unemployed in the unemployed population. Börsch-Supan (1991) find that a large proportion of unemployed women is associated with outward shifts in Germany's Beveridge curves. The impact of long-term unemployment is referred as unemployment hysteresis (Blanchard and Summers, 1987). Owing to human capital deterioration, long-term unemployed workers might experience lower search effectiveness and ability to be matched with a vacant job. I use 
long-term unemployment (measured as the percentage of unemployed workers who have been unemployed for more than a year) to test the unemployment hysteresis theory. Ideally I would also like to control for the age composition of the unemployed population, but at this stage of the paper, I have not found the necessary data for the five countries and their regions. Following Samson (1994), I also control for the proportion of women and young people (between 16 and 25 year-old) in the labor force. Because these two groups of workers have lower levels of attachment to their jobs, an increase in their ratios in labor force would raise both the unemployment rate and the vacancy rate, thus causing an outward shift of the Beveridge curve.

Second, shifts can be explained by the implementation of labor market reforms. Nickell and van Ours (2000) list how some labor policies and institutions can shift the Beveridge curve. First, more generous unemployment benefit systems tend to make unemployed workers more choosy about which jobs they would accept. Empirical evidence suggests that unions and collective wage agreements induce wage pressure which translates into higher equilibrium unemployment (thus, an increase in unemployment for a given vacancy rate, i.e. an outward shift of the Beveridge curve). As for minimum wage legislation, the authors point out that there is little consensus on the effect of such legislation on unemployment, but that in countries where the minimum wage is not adjusted for young workers, it leads to higher youth unemployment rates. Furthermore, employment protection laws are likely to increase long-term unemployment by raising labor cost.

While very few papers control for the effects of labor institutions (with the exception of Kosfeld et al. (2007) and Samson (1994)), I control for the five aforementioned aspects of national wage-setting institutions: the existence of a legal minimum wage law (with a dummy equal to 1 if the country has a minimum wage legislation in place) ${ }^{3}$, labor union density (percentage of union members among the employee population), the size of unemployment benefits relative to the national economy (as a percentage of GDP), employment protection legislation (EPL)

\footnotetext{
${ }^{3}$ The UK did not have a national legislation until 2000 and Germany still does not have an official national minimum wage legislation.
} 
and the degrees of centralization and coordination in the wage-setting process. EPL refers to all types of employment protection measures, whether grounded primarily in legislation, court rulings, collectively bargained conditions of employment or customary practice. The degrees of centralization and coordination in the wage-setting process take values between 1 and 5 a value of 5 indicates wage-setting bargaining and agreements organized at the national level (and not at the plant or industry level). The coordination and centralization parameters are combined into a single variable by taking the average of the two measures. I then create a dummy variable for high level of coordination/centralization when the average of the two is larger than 4. These data are obtained from OECD (2004). They are measured only at the national level, not regional level.

I use regional employment dispersion, sectoral shifts and productivity growth to control for other structural shocks that could hit national and regional economies. Productivity is measured measured as Total Factor Productivity (TFP) ${ }^{4}$. Regional employment dispersion might induce regional mismatches between unemployed workers and job vacancies occurred, forcing unemployed to move to regions where jobs are available. Because this moving process is time-consuming, the economy would experiences periods with higher unemployment rates and vacancies. Abraham and Watcher (1987) and Valletta and Hodge (2006) have shown that increase in regional employment dispersion partly explained the rise in unemployment in the US between 1970 and 1985. Following Abraham and Watcher (1987), regional employment dispersion is measured as

$$
D_{c, t}=\left[\sum_{i=1}^{K} \frac{E_{i, t}}{E_{c, t}}\left(\Delta \log E_{i, t}-\Delta \log E_{c, t}\right)^{2}\right]^{1 / 2}
$$

where $K$ is the number of regions in country $c, E_{i, t}$ is the level of employment in region $i$ and $E_{c, t}$ is the level of employment in country $c$.

Sectoral shifts induce skills mismatch between unemployed workers and unfilled jobs, which results in shifting the Beveridge curve outwards. Based on Lilien (1982), regional sectoral shifts

\footnotetext{
${ }^{4}$ Let GDP be $Y_{t}=K_{t}^{\alpha}\left(A_{t} L_{t}\right)^{1-\alpha}$, then TFP can be expressed as $T F P_{t}=A_{t}=\left[\frac{y_{t}}{k_{t}}\right]^{\frac{1}{1-\alpha}}$ (Caselli, 2004).
} 
are measured as

$$
S_{i, t}=\left[\sum_{j=1}^{N} \frac{x_{i, j, t}}{X_{i, t}}\left(\Delta \log x_{i, j, t}-\Delta \log X_{i, t}\right)^{2}\right]^{1 / 2}
$$

where $N$ is the number of sectors, $x_{i, j, t}$ is the employment in industry $j$, and $X_{i, t}$ is the aggregate employment in region $i$ at time $t$. I use Cambridge Econometrics dataset which decomposes employment in 15 sectors $^{5}$. While TFP growth should induce inward shift of the Beveridge curve, regional employment dispersion and sectoral shifts should be associated with outward shift of the Beveridge curve because they trigger mistmatches in the labor market between unemployed workers and unfilled vacancies.

Finally, I check the effect of business cycles on the stability of the Beveridge curve. As noted earlier, the position on the Beveridge curve can indicate where an economy is in the business cycle, recessions corresponding for instance to points on the upper left section of the curve. Yet, Pissarides (1985) and Börsch-Supan (1991) have shown that if the matching efficiency is a function of productivity and the reservation wage, the Beveridge curve becomes unstable over the business cycle. Cyclical shocks are controlled with the output gap (Kosfeld et al., 2007). Output gap is measured as the difference between real GDP and potential GDP which is computed by detrending real GDP with the Hodrick-Prescott filter. I expect that, when real GDP is above potential GDP (i.e. positive output gap), the unemployment rate decreases for a given vacancy rate, hence causing an inward shift of the curve.

Using national and then regional data, I estimate the following specification:

$$
u_{i t}=\alpha_{i}+\beta_{1}+\beta_{2} v_{i t}+\beta_{3} v_{i t}^{2}+\beta_{4} \mathbf{X}_{i t}+\beta_{5} \mathbf{Z}_{i, t}+\beta_{6} \text { outputgap } i t+\beta_{7} \mathbf{W}_{i t}+\eta_{i t}
$$

where $\alpha_{i}$ is a country/region fixed effect (which helps correcting for possible measurement error), $\mathbf{X}_{i t}$ is the set of variables controlling for the composition of the labor force and unemployment pool, $\mathbf{Z}_{i, t}$ is the set of labor-institution variables, outputgap $i t$ controls for business cycles, and $\mathbf{W}_{i t}$ is the set of variables controlling for structural changes (TFP growth, sectoral

\footnotetext{
${ }^{5}$ Agriculture, Mining, Food, Clothing, Fuel, Electronics, Transport, Other manufacturing, Construction, Wholesale services, Hotel, Telecommunication services, Finance, Other market services, and Non-market services.
} 
shift, regional employment dispersion). The estimation is done in level and not in log-log form so that it yields an estimate of the curve slope (and not of an elasticity). The quadratic term in the vacancy rate is added to measure the convexity of the Beveridge curve. I have also tried Börsch-Supan (1991)'s specification where the unemployment rate is inversely related to the vacancy rate, and have obtained similar results which I do not report in this paper.

Tables 1 and 2 report respectively the summary statistics and pairwise correlation for both country and region data.

-Table 1 here-

-Table 2 here-

\subsection{Country Panel Analysis}

I first conduct the analysis using national data for Belgium, Germany, the Netherlands, Spain and the UK. The results are reported in table 3. The estimates presented in the first two columns are based on ordinary least squares (OLS), while the last two columns' estimates correct for possible simultaneity and endogeneity bias by using instrumental variables (IV) for the vacancy rate and its quadratic term. I use one-year lagged values as IV.Country fixed effects are added to the estimations in columns 2 and 4 which therefore measure variations in unemployment within each country. The Wu-Hausman endogeneity tests reported in columns 3 and 4 clearly indicate that the vacancy rate variable should be treated as endogenous.

When I include country fixed effects, the estimated slope of the Beveridge curve is statistically significant and now equal to -5.05 with OLS and -17.5 with IV. I also find evidence of the convexity of the curve.

The statistically significant coefficients reported on the long-term unemployment variable corroborate the unemployment hysteresis theory and the findings of earlier papers (BörschSupan, 1991; Wall and Zoega, 2002; Kosfeld et al., 2007): when a country experiences more long-term unemployment, its Beveridge curve tends to shift outwards. The other demographic variables do not yield any robust effect. 
Most of the institutional variables do not affect the locus of the Beveridge curves, which could be due to the small sample size and to the lack of variation in these variables at the national level. Stricter EPL and higher union density are associated with lower unemployment rates. More generous unemployment benefits are weakly associated with an outward shift of the Beveridge. Similarly I do not find any robust evidence that regional dispersion and sectoral shift of employment cause outward shift of the Beveridge curve.

As for the business cycles, I do not find strong evidence that business cycles affect the locus of the Beveridge curve, even when I introduce a lag on the output gap variable.

-Table 3 here-

\subsection{Regional Panel Analysis}

I then run a similar analysis at the regional level. These results are presented in table 4. The estimations are run with OLS and then instrumental variables. Columns 1 and 4 do not include any country or region fixed effects to study variations among all of the regions included in the sample. In columns 2 and 5, I introduce country dummy variables to measure variations within each country over time. In columns 3 and 6 , the specifications include regional fixed effects, and thus capture variations within each region over time.

The estimated slopes are less steep than the estimation using country data (-1.2 to - 2.9). The coefficient on the quadratic term in the vacancy rate is positive and significant in most specifications, implying that regional Beveridge curves are also convex. The regional analysis confirms the unemployment hysteresis theory, as the coefficient on the long-term unemployment remains positive and significant in all of the specifications reported in the table. A larger share of women among the unemployed is associated with an inward shift of the Beveridge curve. This unexpected result could explained by the fact that women are more likely to accept part-time jobs to return to work. There is clearer evidence of the impact of the labor force composition on unemployment. More youngster and women in the labor force are associated with an outward shift of the Beveridge curve. 
As for the institutional factors, the regional panel analysis supports the hypothesis that regions in countries with more generous unemployment benefits and minimum wage laws have Beveridge curves further from the origin. Higher union memberships are only associated with outward shift when the specification includes regional fixed effects. Similar to the findings presented in table 3, I find that the sign on the union density and the EPL variables changes when I do not include any region or country dummy variables in the estimation.

As for the other structural factors, the results presented in table 4 provide little evidence of the effects of sectoral shifts, as the coefficient is positive and significant only when the specification includes regional fixed effects. As expected, I find that productivity growth is associated with improvement in regional labor markets (inward shifts of the Beveridge curves).

The results of table 4 provide also evidence of the impact of the business cycle on the locus of the Beveridge curve. As expected, a positive output gap is associated with inward shifts of the Beveridge curve. This finding contrasts with the absence of effects when the analysis is carried out with country data. It however corroborates Abraham and Watcher (1987)'s argument that if an economic recession induces mismatches in regional labor markets (such as dispersion of employment growth), it can cause shifts in regional Beveridge curves.

-Table 4 here-

\section{Conclusion}

Combining data from EU countries and their regions, this paper examines the stability and movements in the unemployment-vacancy relationship embodied in the Beveridge curve. These five European countries have experienced very distinct relationships between their unemployment rates and vacancy rates. Germany exhibits the clearest example of a Beveridge curve with a rather constant slope, shifting outwards. In Belgium and Spain, the Beveridge curves are quite vertical from 1975 to the mid-1980s. Three countries - The UK, the Netherlands, and Belgium - experienced an inward shift in their Beveridge curves since the late 1990s. This inward shift is also observed at the regional level. 
This paper also investigates which factors, structural and cyclical, are behind the instability of these curves. The basic Beveridge curve regression is augmented with variables capturing structural variables, such as long-term unemployment, labor market institutions and the reallocation of labor across regions and sectors. The results presented in this paper provide evidence of unemployment hysteresis at the national and regional levels, as well as the importance of labor market institutions, to explain the position of the Beveridge curve. The Beveridge curve tends to shift outwards when a country has a minimum wage law and generous unemployment benefits. Among the other structural shocks included in the study, productivity growth is associated with inward shift of the curve, while evidence of the effects of employment regional dispersion and sectoral shifts is less robust. Business cycles - measured with the output gap - affect the locus of the Beveridge curve at the regional level but not at the country level, which is in line with Abraham and Watcher (1987)'s argument that the business cycle induces mismatches in regional labor markets. These regression results therefore do not support the notion that cyclical shocks generate only movements along a stable Beveridge curve.

Because common or idiosyncratic shocks might generate some interregional spillovers, further research should examine whether spatial dependencies among EU regions could also affect the stability of regional Beveridge curves.

What can we learn from these regression results? They first provide more evidence to the argument that rigidities in the labor market limit the ability of economies to adjust to shocks (Blanchard and Wolfers, 2000), notably by hampering the matching between jobs and unemployed workers. The findings presented also highlight the importance of long-term unemployment to the more general unemployment problem in Europe.

\section{References}

Abraham, K. G. and M. Watcher, "Help-Wanted Advertising, Job Vacancies, and Unemployment," Brookings Papers on Economic Activity, 1987, 1987 (1), 207-248.

Antolín, P., "Unemployment flows and vacancies in Spain," 1994. WP-EC 94-05. Instituto Valenciano de Investigaciones Económicas. 
Blanchard, O. J. and J. Wolfers, "The Role of Shocks and Institutions in the Rise of European Unemployment: the Aggregate Evidence.," The Economic Journal, March 2000, $110,1-33$.

_ and L. H. Summers, "Hysteresis in unemployment," European Economic Review, 1987, $31(1 / 2), 288-295$.

_ and P. Diamond, "Ranking, unemployment duration and wages," Review of Economic Studies, July 1994, 61 (3), 417-434.

_ , _ , R. E. Hall, and J. Yellen, "The Beveridge curve," Brookings Papers on Economic Activity, 1989, 1, 1-76.

Börsch-Supan, A. H., "Panel data analysis of the Beveridge curve: Is there a macroeconomic relation between the rate of unemployment and the vacancy rate?," Economica, August 1991, 58 (231), 279-297.

Bowden, R. J., "On the existence and secular stability of u-v Loci," Economica, 1980, 47 (185), 35-50.

Caselli, F., "Accounting for cross-country income differences," NBER working paper, October 2004, (10828).

Coles, M. G. and E. Smith, "Cross-Section Estimation of the Matching Function: Evidence from England and Wales," Economica, Nov. 1996, 63 (252), 589-597.

Gorter, C. and J. van Ours, "Matching unemployment and vacancies in regional labor market: an empirical analysis for the Netherlands," Papers in Regional Science, 1994, 73 (2), 153-167.

_ , P. Nijkamp, and E. Pels, "Vacancy dynamics and labor market efficiency in the Dutch labor market," Growth and Change, 1997, 28 (2), 173-200.

Jackman, R. A., C. A. Pissarides, and S. Savouri, "Labour market policies and unemployment in the OECD," Economic Policy, 1990, 11, 449-90.

_ , R. Layard, and C. A. Pissarides, "On Vacancies," Oxford Bulletin of Economics and Statistics, 1989, 51 (4), 377-94.

Kosfeld, R., C. Dreger, and H-F. Eckey, "On the stability of the German Beveridge curve: a spatial econometric perspective," Annals of Regional Science, 2007.

Lilien, D. M., "Sectoral Shifts and Cyclical Unemployment," The Journal of Political Economy, August 1982, 90 (4), 777-793.

Nickell, S. and J. van Ours, "The Netherlands and the United Kingdom: A European unemployment miracle?," Economic Policy, April 2000, 15 (30), 137-180.

OECD, Employment Outlook, Paris: OECD, 2004.

Petrongolo, B. and C. A. Pissarides, "Looking into the black box: A survey of the matching function," Journal of Economic Literature, 2001, 39, 390-431. 
Pissarides, C. A., "Short-run dynamics of unemployment, vacancies, and real wages," American Economic Review, 1985, 75, 676-690.

_ , "Loss of skills during unemployment and the persistence of employment shocks," Quarterly Journal of Economics, 1992, 10\%, 1371-1392.

_, Equilibrium Unemployment Theory, second ed., Oxford: Basil Blackwell, 2000.

Røed, K., "Hysteresis in unemployment," Journal of Economic Surveys, December 1997, 11 (4), 389-418.

Samson, L., "The Beveridge curve ans regional disparities in Canada," Applied Economics, 1994, 26, 937-947.

Valletta, R. G., "Why has the US Beveridge curve shifted back? New evidence using regional data," 2005. Federal Reserve Bank of San Francisco, Working paper 2005-25.

- and J. Hodge, "Job matching : Evidence from the Beveridge curve," FRBSF Economic Letter, April 2006, (2006-08).

Wall, H. J. and G. Zoega, "The British Beveridge curve: A tale of ten regions," Oxford Bulletin of Economics and Statistics, 2002, 64 (3), 257-276. 
Figures and Tables

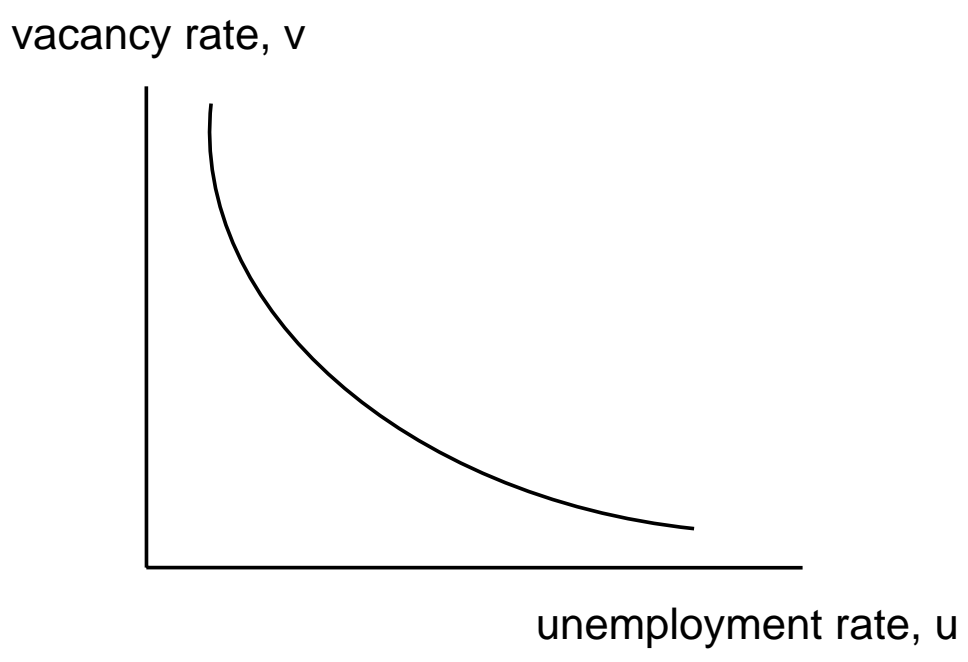

Figure 1: The Beveridge Curve 

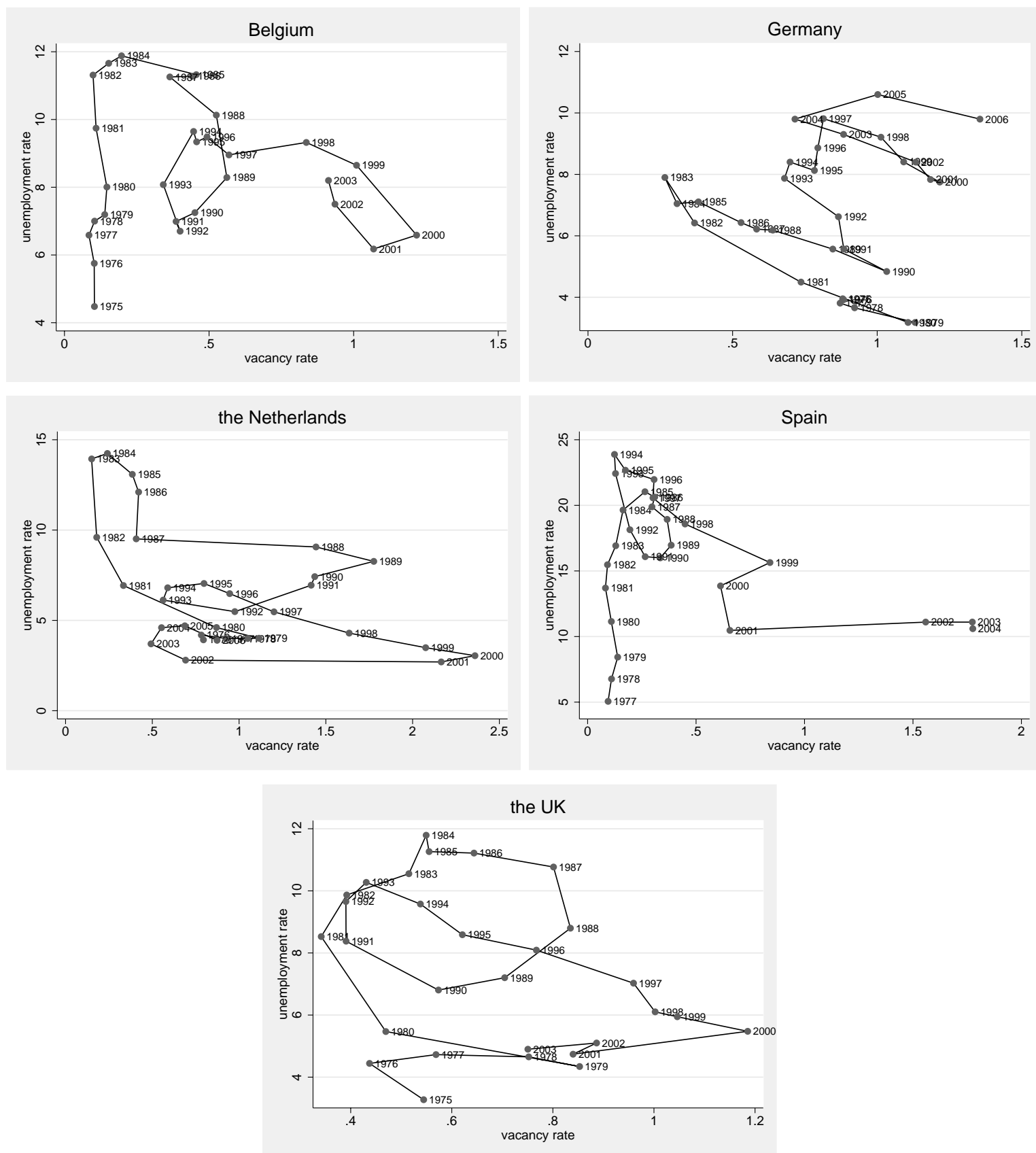

Figure 2: National Beveridge curves 


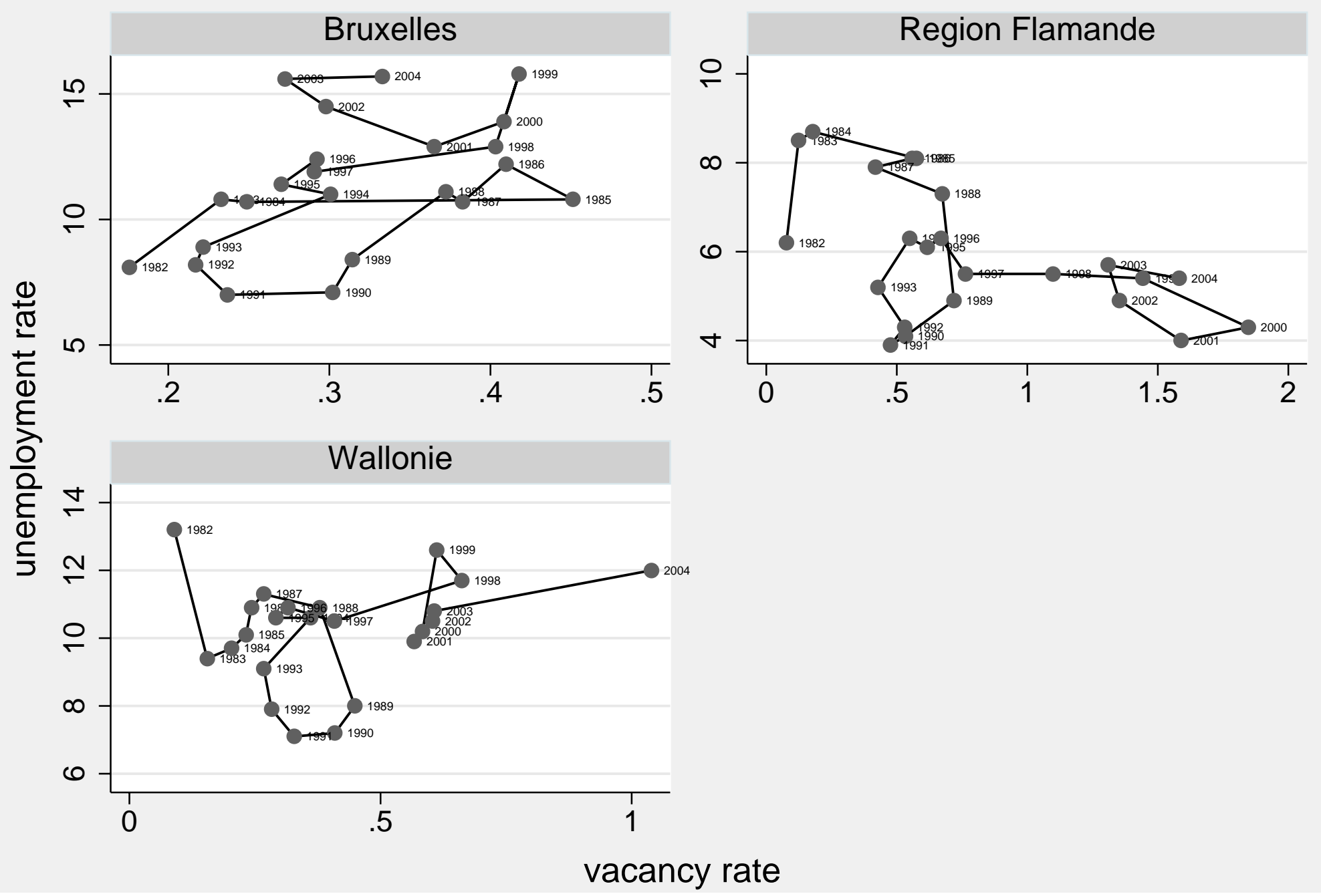

Figure 3: The Belgian Beveridge Curves 

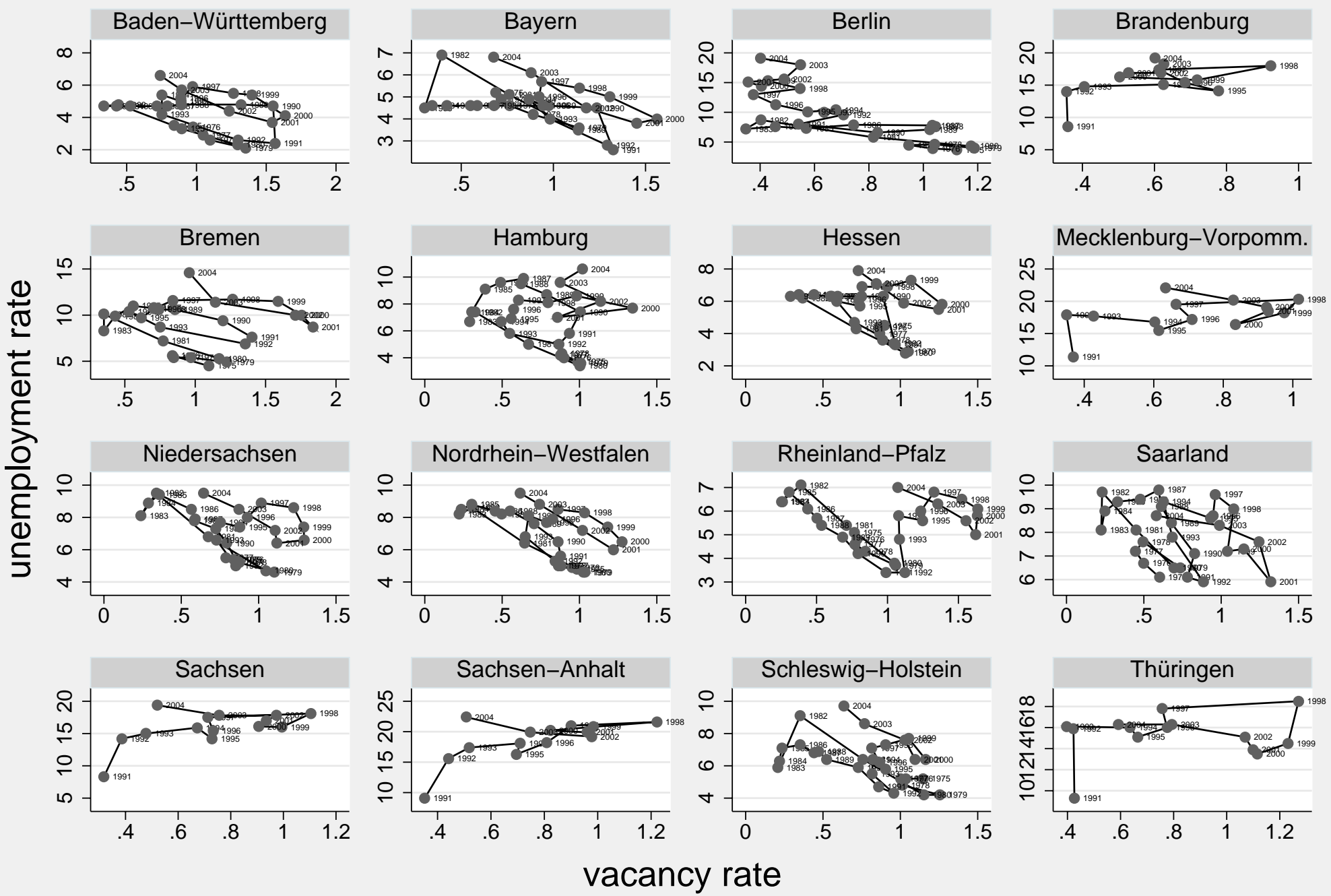

Figure 4: The German Beveridge Curves 

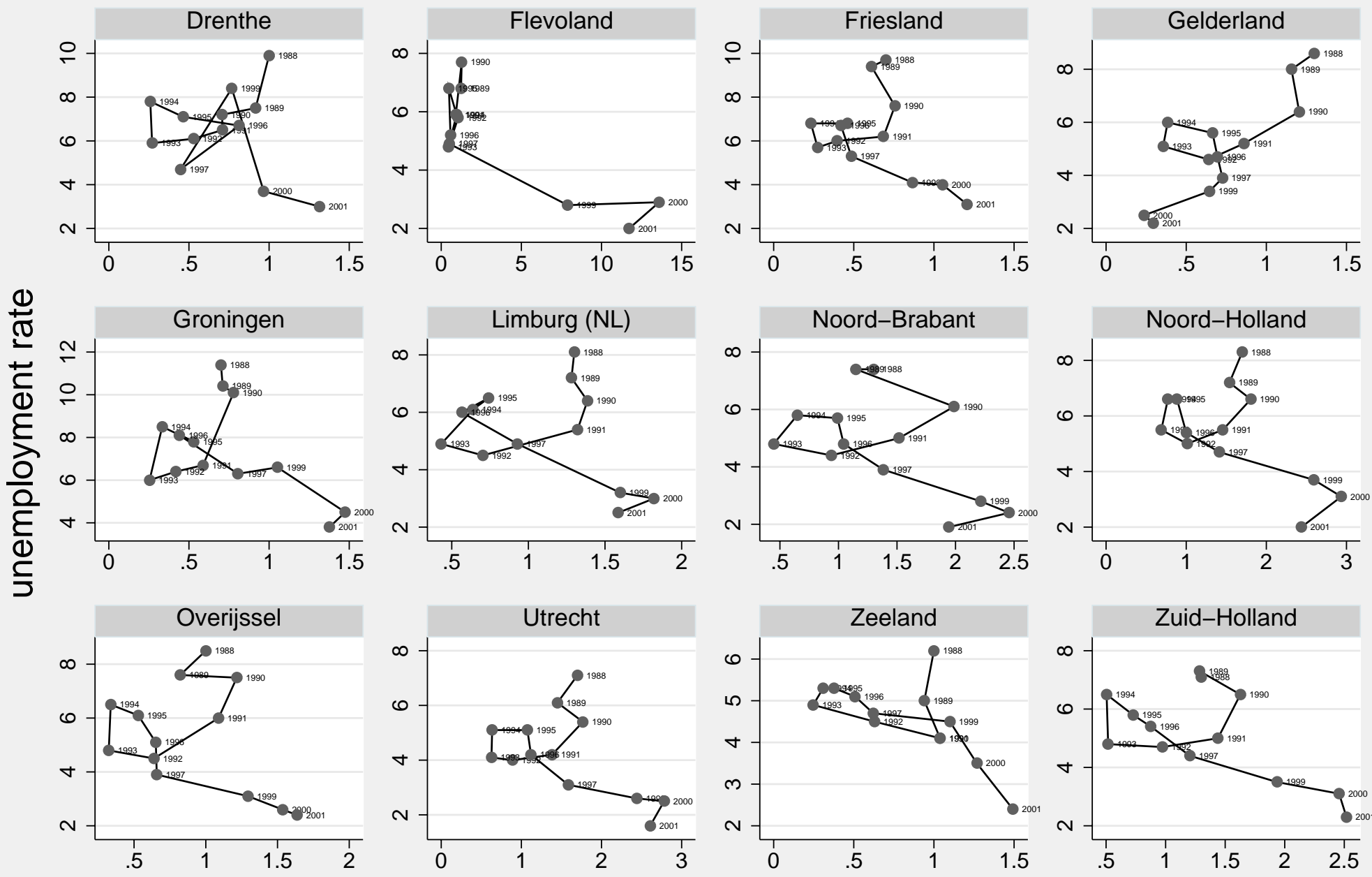

Figure 5: The Dutch Beveridge Curves 

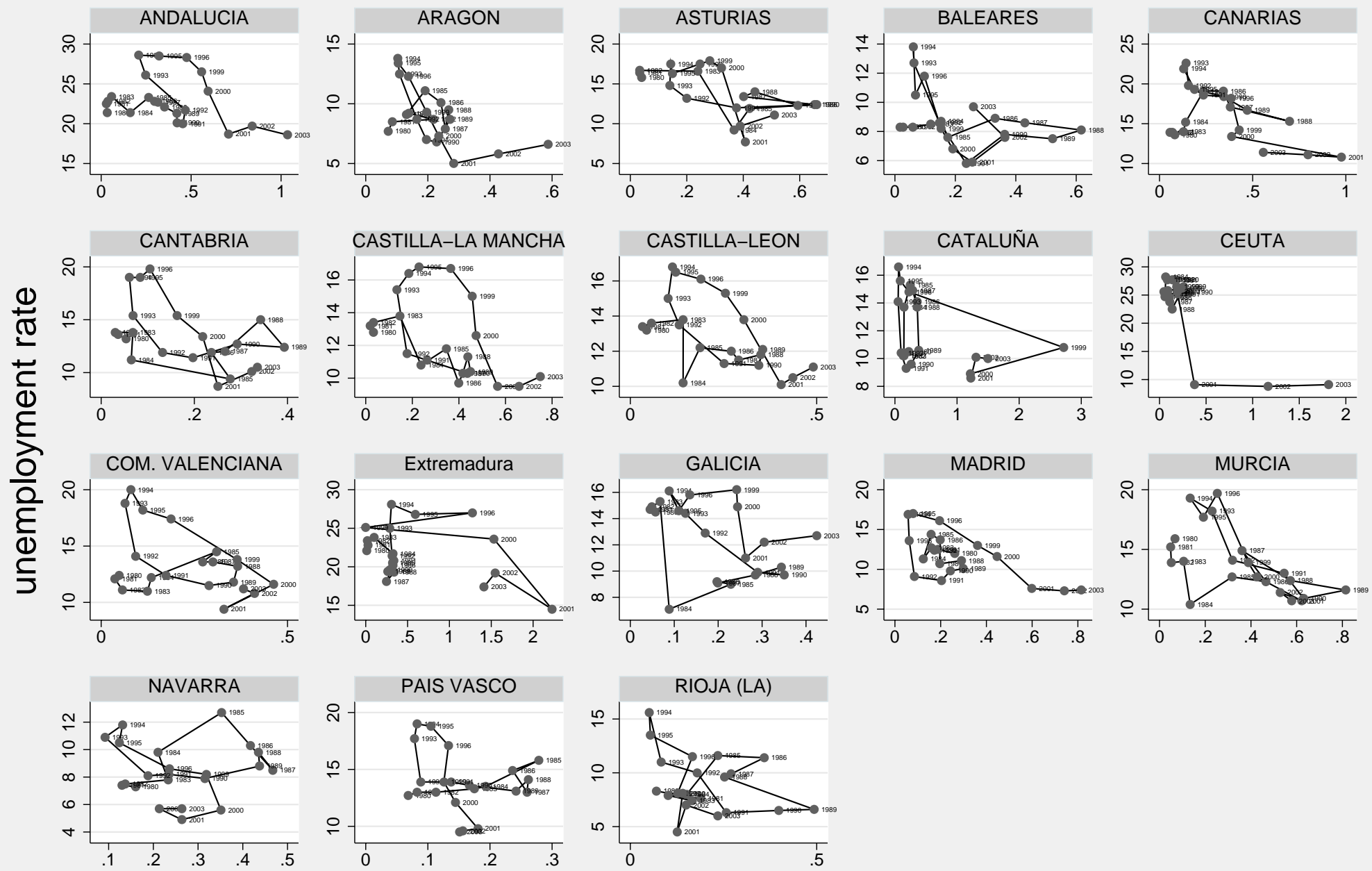

vacancy rate

Figure 6: The Spanish Beveridge Curves 

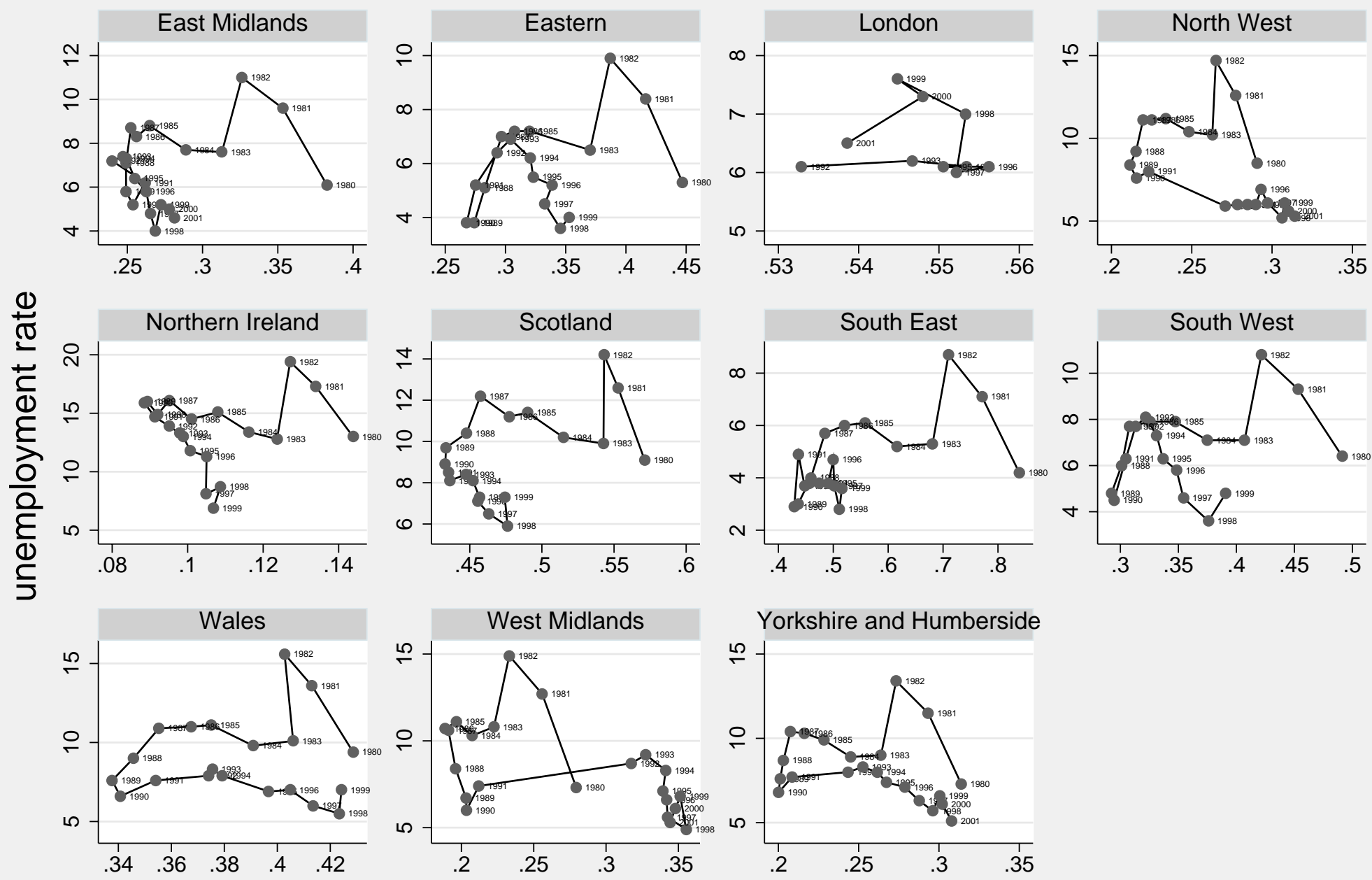

\section{vacancy rate}

Figure 7: The British Beveridge Curves 
Table 1: Summary statistics

\begin{tabular}{|c|c|c|c|c|c|}
\hline Variable & Obs & Mean & Std. Dev & Min & $\operatorname{Max}$ \\
\hline EPL & 95 & 2.453 & 1.019 & 0.599 & 3.815 \\
\hline Union Density & 129 & 33.235 & 14.309 & 7.376 & 56.042 \\
\hline Unempl. Benefits & 120 & 3.081 & 3.325 & 0.202 & 12.328 \\
\hline Min. wage law & 150 & 0.633 & 0.484 & 0.000 & 1.000 \\
\hline Coordination/Central. & 140 & 3.045 & 0.984 & 1.000 & 4.000 \\
\hline Long-term unempl. & 97 & 49.350 & 11.066 & 20.489 & 76.167 \\
\hline Female share in unempl. & 100 & 47.660 & 9.319 & 23.716 & 62.094 \\
\hline Female share in labor force & 112 & 40.622 & 3.428 & 30.132 & 46.043 \\
\hline Young share in the labor force & 104 & 16.418 & 3.978 & 9.635 & 23.094 \\
\hline Sectoral shift & 145 & 0.028 & 0.022 & 0.007 & 0.249 \\
\hline Regional Dispersion & 137 & 1.243 & 2.479 & 0.097 & 28.746 \\
\hline Output gap & 135 & 0.000 & 0.017 & -0.071 & 0.097 \\
\hline TFP growth & 130 & 0.754 & 7.534 & -29.959 & 23.090 \\
\hline \multicolumn{6}{|l|}{ Region Data } \\
\hline Variable & Obs & Mean & Std. Dev & Min & Max \\
\hline EPL & 1121 & 2.556 & 1.026 & 0.599 & 3.815 \\
\hline Union Density & 1506 & 27.815 & 12.251 & 7.376 & 56.042 \\
\hline Unempl. Benefits & 1416 & 3.909 & 3.466 & 0.202 & 12.328 \\
\hline Min. wage law & 1770 & 0.573 & 0.495 & 0.000 & 1.000 \\
\hline Coordination/Central. & 1652 & 3.049 & 0.953 & 1.000 & 4.000 \\
\hline Long-term unempl. & 860 & 43.566 & 11.942 & 12.310 & 77.800 \\
\hline Female share in unempl. & 1087 & 47.054 & 10.968 & 10.616 & 85.366 \\
\hline Female share in labor force & 1182 & 40.196 & 4.546 & 22.692 & 48.826 \\
\hline Young share in the labor force & 1184 & 16.282 & 4.139 & 7.443 & 27.053 \\
\hline Sectoral shift & 1602 & 8.183 & 37.745 & 0.507 & 886.197 \\
\hline Output gap & 1690 & -0.024 & 2.063 & -17.343 & 18.047 \\
\hline TFP growth & 1527 & -1.254 & 9.792 & -77.362 & 58.352 \\
\hline
\end{tabular}




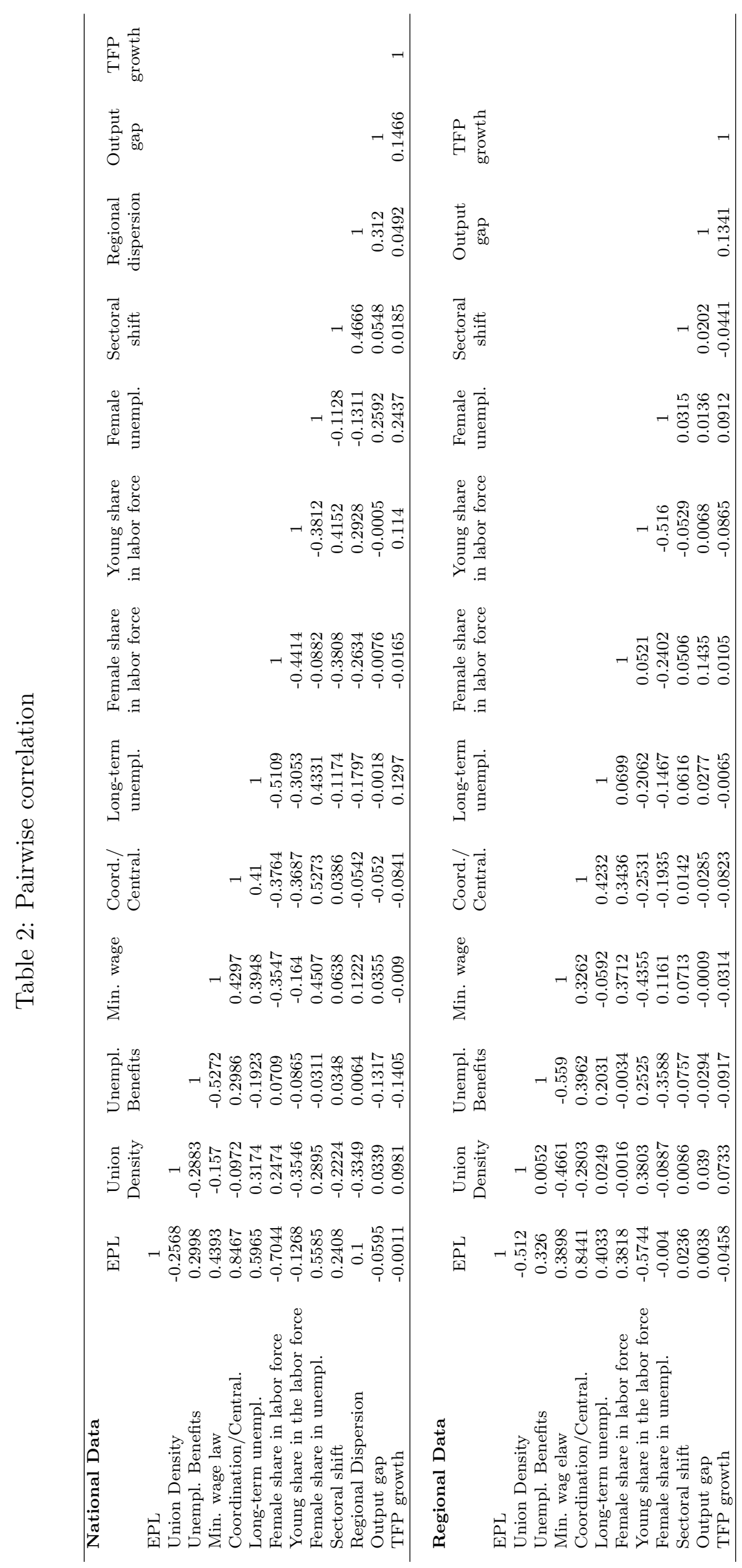


Table 3: National Panel

\begin{tabular}{|c|c|c|c|c|}
\hline & \multicolumn{4}{|c|}{ Dependent variable: national unemployment rate } \\
\hline & $(1)$ & $(2)$ & $(3)$ & $(4)$ \\
\hline & OLS & OLS & IV & IV \\
\hline Vacancy rate & $\begin{array}{c}-10.0086^{* * *} \\
{[3.6291]}\end{array}$ & $\begin{array}{c}-5.0490^{*} \\
{[2.9632]}\end{array}$ & $\begin{array}{c}-21.4197^{* * *} \\
{[7.1637]}\end{array}$ & $\begin{array}{c}-17.5068^{* *} \\
{[7.7816]}\end{array}$ \\
\hline Vacancy rate ${ }^{2}$ & $\begin{array}{l}2.9948^{*} \\
{[1.5625]}\end{array}$ & $\begin{array}{l}1.6806 \\
{[1.3283]}\end{array}$ & $\begin{array}{l}8.0227^{* *} \\
{[3.5753]}\end{array}$ & $\begin{array}{l}7.3139 * \\
{[4.1421]}\end{array}$ \\
\hline EPL & $\begin{array}{l}-0.8397 \\
{[1.3854]}\end{array}$ & $\begin{array}{c}-1.6628^{*} \\
{[0.9031]}\end{array}$ & $\begin{array}{l}-1.9685 \\
{[1.5869]}\end{array}$ & $-2.3050^{* * * *}$ \\
\hline Union Density & $\begin{array}{c}-0.1524^{* * *} \\
{[0.0438]}\end{array}$ & $\begin{array}{c}0.0369 \\
{[0.0788]}\end{array}$ & $\begin{array}{c}-0.1651^{* * *} \\
{[0.0432]}\end{array}$ & $\begin{array}{c}0.0616 \\
{[0.0817]}\end{array}$ \\
\hline Unempl. Benefits & $\begin{array}{c}0.1956 \\
{[0.2074]}\end{array}$ & $\begin{array}{c}0.3744 \\
{[0.5157]}\end{array}$ & $\begin{array}{l}0.3143^{*} \\
{[0.1814]}\end{array}$ & $\begin{array}{c}0.3974 \\
{[0.4886]}\end{array}$ \\
\hline Min. wage law & $\begin{array}{l}0.4363 \\
{[1.6701]}\end{array}$ & $\begin{array}{c}0.8454 \\
{[0.9680]}\end{array}$ & $\begin{array}{c}0.6357 \\
{[1.4021]}\end{array}$ & $\begin{array}{l}1.4258 \\
{[1.0616]}\end{array}$ \\
\hline Coordination/Central. & $\begin{array}{l}-1.3384 \\
{[1.0752]}\end{array}$ & $\begin{array}{l}-0.9162 \\
{[1.8710]}\end{array}$ & $\begin{array}{l}-0.7656 \\
{[1.1685]}\end{array}$ & $\begin{array}{l}1.8278 \\
{[2.0963]}\end{array}$ \\
\hline Long-term unempl. & $\begin{array}{l}0.1304^{* *} \\
{[0.0620]}\end{array}$ & $\begin{array}{l}0.1106^{* *} \\
{[0.0512]}\end{array}$ & $\begin{array}{c}0.1465 * * * \\
{[0.0554]}\end{array}$ & $\begin{array}{c}0.1417^{* * *} \\
{[0.0429]}\end{array}$ \\
\hline Female share in unempl. & $\begin{array}{l}-0.0077 \\
{[0.0841]}\end{array}$ & $\begin{array}{l}-0.1115 \\
{[0.0684]}\end{array}$ & {$[0.0145$} & $\begin{array}{l}-0.0464 \\
{[0.0713]}\end{array}$ \\
\hline Female share in labor force & $\begin{array}{c}-0.8296^{*} \\
{[0.4776]}\end{array}$ & $\begin{array}{c}0.0237 \\
{[0.3612]}\end{array}$ & $\begin{array}{l}-0.6325 \\
{[0.4021]}\end{array}$ & $\begin{array}{c}0.0385 \\
{[0.2718]}\end{array}$ \\
\hline Young share in the labor force & $\begin{array}{l}-0.2667 \\
{[0.1901]}\end{array}$ & $\begin{array}{l}0.3683^{*} \\
{[0.2067]}\end{array}$ & $\begin{array}{c}-0.2977^{*} \\
{[0.1723]}\end{array}$ & $\begin{array}{c}0.1598 \\
{[0.2144]}\end{array}$ \\
\hline Sectoral shift & $\begin{array}{l}-0.3918 \\
{[0.4392]}\end{array}$ & $\begin{array}{l}-0.3649 \\
{[0.2300]}\end{array}$ & $\begin{array}{l}-0.2856 \\
{[0.4059]}\end{array}$ & $\begin{array}{l}-0.198 \\
{[0.2861]}\end{array}$ \\
\hline Regional Dispersion & $\begin{array}{c}0.486 \\
{[0.3575]}\end{array}$ & $\begin{array}{l}0.4519^{* *} \\
{[0.1939]}\end{array}$ & $\begin{array}{c}0.3649 \\
{[0.3191]}\end{array}$ & $\begin{array}{c}0.2887 \\
{[0.2389]}\end{array}$ \\
\hline Output gap & $\begin{array}{l}-23.0139 \\
{[27.5362]}\end{array}$ & $\begin{array}{c}-48.5259^{* *} \\
{[23.3034]}\end{array}$ & $\begin{array}{l}-5.2696 \\
{[26.2604]}\end{array}$ & $\begin{array}{l}-31.7751 \\
{[22.2078]}\end{array}$ \\
\hline TFP Growth & $\begin{array}{l}-0.0743 \\
{[0.0466]}\end{array}$ & $\begin{array}{l}-0.0295 \\
{[0.0300]}\end{array}$ & $\begin{array}{c}-0.026 \\
{[0.0491]}\end{array}$ & $\begin{array}{c}0.0098 \\
{[0.0330]}\end{array}$ \\
\hline Constant & $\begin{array}{c}58.1139^{* *} \\
{[23.9390]}\end{array}$ & $\begin{array}{c}9.9294 \\
{[19.7937]}\end{array}$ & $\begin{array}{c}54.2371^{* * *} \\
{[19.9700]}\end{array}$ & $\begin{array}{c}5.2462 \\
{[20.9318]}\end{array}$ \\
\hline country fixed effect & no & yes & no & yes \\
\hline Observations & 71 & 71 & 71 & 71 \\
\hline $\begin{array}{l}\text { R-squared } \\
\text { Hausman test }\end{array}$ & 0.833 & $\begin{array}{c}0.771 \\
248.94 \\
\end{array}$ & 0.802 & 0.645 \\
\hline $\begin{array}{l}\text { Endogeneity test } \\
\text { (p-value) }\end{array}$ & & & $\begin{array}{c}3.951 \\
(0.025)\end{array}$ & $\begin{array}{c}10.42 \\
(0.000)\end{array}$ \\
\hline
\end{tabular}

* significant at $10 \% ;{ }^{* *}$ significant at $5 \% ; * * *$ significant at $1 \%$ 
Table 4: Regional Panel

\begin{tabular}{|c|c|c|c|c|c|c|}
\hline & \multicolumn{6}{|c|}{ Dependent variable:regional unemployment rate } \\
\hline & (1) & $(2)$ & $(3)$ & $(4)$ & $(5)$ & (6) \\
\hline & OLS & OLS & OLS & IV & IV & IV \\
\hline Vacancy & $\begin{array}{c}-2.4064^{* * *} \\
{[0.7578]}\end{array}$ & $\begin{array}{c}-1.1664^{*} \\
{[0.6011]}\end{array}$ & $\begin{array}{c}-1.1739^{* * *} \\
{[0.3382]}\end{array}$ & $\begin{array}{c}-4.6623^{* * *} \\
{[1.0532]}\end{array}$ & $\begin{array}{c}-2.8831^{* * * *} \\
{[0.8728]}\end{array}$ & $\begin{array}{c}-2.9120^{* * * *} \\
{[0.4946]}\end{array}$ \\
\hline${\text { Vacancy } \text { rate }^{2}}^{2}$ & $\begin{array}{c}0.1741^{* * *} \\
{[0.0634]}\end{array}$ & $\begin{array}{c}0.0682 \\
{[0.0496]}\end{array}$ & $\begin{array}{c}0.0768^{* * *} \\
{[0.0279]}\end{array}$ & $\begin{array}{c}0.3414^{* * *} \\
{[0.0810]}\end{array}$ & $\begin{array}{c}0.1965^{* * *} \\
{[0.0671]}\end{array}$ & $\begin{array}{c}0.2100^{* * *} \\
{[0.0384]}\end{array}$ \\
\hline EPL & $\begin{array}{c}1.4205^{* * *} * \\
{[0.4909]}\end{array}$ & $\begin{array}{c}-4.5099^{* * *} \\
{[0.5222]}\end{array}$ & $\begin{array}{c}-4.0667 * * * \\
{[0.2907]}\end{array}$ & $\begin{array}{c}0.6686 \\
{[0.5592]}\end{array}$ & $\begin{array}{c}-4.8028^{* * *} \\
{[0.5470]}\end{array}$ & $\begin{array}{c}-4.3510^{* * * *} \\
{[0.3114]}\end{array}$ \\
\hline Union Density & $\begin{array}{c}-0.1140 * * * \\
{[0.0206]}\end{array}$ & $\begin{array}{c}0.0342 \\
{[0.0557]}\end{array}$ & $\begin{array}{c}0.1814^{* * * *} \\
{[0.0330]}\end{array}$ & $\begin{array}{c}-0.1214^{* * *} \\
{[0.0216]}\end{array}$ & $\begin{array}{c}0.0093 \\
{[0.0563]}\end{array}$ & $\begin{array}{c}0.1509 * * * \\
{[0.0346]}\end{array}$ \\
\hline Unempl. Benefits & $\begin{array}{c}0.3563^{* * *} \\
{[0.1117]}\end{array}$ & $\begin{array}{c}0.5561^{* * *} \\
{[0.1218]}\end{array}$ & $\begin{array}{c}0.6208^{* * *} \\
{[0.0949]}\end{array}$ & $\begin{array}{c}0.3404^{* * *} \\
{[0.1090]}\end{array}$ & $\begin{array}{c}0.5000^{* * *} \\
{[0.1229]}\end{array}$ & $\begin{array}{c}0.5380^{* * * *} \\
{[0.0872]}\end{array}$ \\
\hline Min. wage law & $\begin{array}{c}2.4878^{* * * *} \\
{[0.8147]}\end{array}$ & $\begin{array}{c}2.9498^{* * *} \\
{[0.6090]}\end{array}$ & $\begin{array}{c}2.0318^{* * *} \\
{[0.4185]}\end{array}$ & $\begin{array}{l}1.9342^{* *} \\
{[0.7811]}\end{array}$ & $\begin{array}{c}2.7671^{* * * *} \\
{[0.6312]}\end{array}$ & $\begin{array}{c}1.8461^{* * *} \\
{[0.4009]}\end{array}$ \\
\hline Coordination/Central. & $\begin{array}{c}-2.0478^{* * *} \\
{[0.6598]}\end{array}$ & $\begin{array}{l}-2.8761 \\
{[1.7475]}\end{array}$ & $\begin{array}{l}-1.1625 \\
{[0.8594]}\end{array}$ & $\begin{array}{l}-0.6546 \\
{[0.8107]}\end{array}$ & $\begin{array}{l}-2.2573 \\
{[1.6869]}\end{array}$ & $\begin{array}{l}-0.6385 \\
{[0.8788]}\end{array}$ \\
\hline Long-term unempl. & $\begin{array}{c}0.1687^{* * *} \\
{[0.0160]}\end{array}$ & $\begin{array}{c}0.1506^{* * *} \\
{[0.0135]}\end{array}$ & $\begin{array}{c}0.0887^{* * * *} \\
{[0.0105]}\end{array}$ & $\begin{array}{c}0.1481^{* * * *} \\
{[0.0172]}\end{array}$ & $\begin{array}{c}0.1371^{* * * *} \\
{[0.0144]}\end{array}$ & $\begin{array}{c}0.0788^{* * * *} \\
{[0.0109]}\end{array}$ \\
\hline Female share in unempl. & $\begin{array}{l}-0.0075 \\
{[0.0284]}\end{array}$ & $\begin{array}{l}-0.0268 \\
{[0.0217]}\end{array}$ & $\begin{array}{c}-0.0564^{* * *} * \\
{[0.0148]}\end{array}$ & $\begin{array}{l}-0.0168 \\
{[0.0314]}\end{array}$ & $\begin{array}{l}-0.0272 \\
{[0.0238]}\end{array}$ & $\begin{array}{c}-0.0626^{* * *} \\
{[0.0172]}\end{array}$ \\
\hline Female share in labor force & $\begin{array}{c}0.2338^{* * *} * \\
{[0.0816]}\end{array}$ & $\begin{array}{c}0.5263^{* * *} \\
{[0.0676]}\end{array}$ & $\begin{array}{l}-0.0705 \\
{[0.0791]}\end{array}$ & $\begin{array}{c}0.2469 * * * \\
{[0.0812]}\end{array}$ & $\begin{array}{c}0.5269^{* * *} \\
{[0.0671]}\end{array}$ & $\begin{array}{l}-0.0724 \\
{[0.0806]}\end{array}$ \\
\hline Young share in the labor force & $\begin{array}{c}0.1200^{* *} \\
{[0.0576]}\end{array}$ & $\begin{array}{c}0.9114^{* * *} \\
{[0.0662]}\end{array}$ & $\begin{array}{c}0.3744 * * * \\
{[0.0526]}\end{array}$ & $\begin{array}{c}0.1516^{* *} \\
{[0.0595]}\end{array}$ & $\begin{array}{c}0.9114^{* * * *} \\
{[0.0664]}\end{array}$ & $\begin{array}{c}0.3682^{* * *} \\
{[0.0502]}\end{array}$ \\
\hline Sectoral shift & $\begin{array}{c}0.606 \\
{[1.0114]}\end{array}$ & $\begin{array}{c}0.5098 \\
{[0.6921]}\end{array}$ & $\begin{array}{l}0.4240^{*} \\
{[0.2352]}\end{array}$ & $\begin{array}{l}1.2316 \\
{[1.1833]}\end{array}$ & $\begin{array}{c}0.931 \\
{[0.7880]}\end{array}$ & $\begin{array}{c}0.7208^{* * * *} \\
{[0.2190]}\end{array}$ \\
\hline Output gap & $\begin{array}{c}-0.2157 * * * \\
{[0.0763]}\end{array}$ & $\begin{array}{c}-0.2765^{* * *} \\
{[0.0715]}\end{array}$ & $\begin{array}{c}-0.1979 * * * \\
{[0.0597]}\end{array}$ & $\begin{array}{c}-0.1564^{* *} \\
{[0.0738]}\end{array}$ & $\begin{array}{c}-0.2395 * * * \\
{[0.0699]}\end{array}$ & $\begin{array}{c}-0.1538^{* * * *} \\
{[0.0529]}\end{array}$ \\
\hline TFP Growth & $\begin{array}{c}-0.0941 * * * \\
{[0.0205]}\end{array}$ & $\begin{array}{c}-0.0686^{* * *} \\
{[0.0159]}\end{array}$ & $\begin{array}{c}-0.0197^{* *} \\
{[0.0083]}\end{array}$ & $\begin{array}{c}-0.0876^{* * *} \\
{[0.0204]}\end{array}$ & $\begin{array}{c}-0.0635^{* * *} \\
{[0.0157]}\end{array}$ & $\begin{array}{c}-0.0193^{* *} \\
{[0.0082]}\end{array}$ \\
\hline Constant & $\begin{array}{l}-5.3299 \\
{[4.4684]}\end{array}$ & $\begin{array}{c}-19.8138^{* * *} \\
{[7.3762]}\end{array}$ & $\begin{array}{c}11.7505^{* *} \\
{[5.0743]}\end{array}$ & $\begin{array}{l}-5.3979 \\
{[4.4878]}\end{array}$ & $\begin{array}{c}-18.2467^{* *} \\
{[7.2936]}\end{array}$ & $\begin{array}{c}14.3336^{* * *} \\
{[4.821]}\end{array}$ \\
\hline country fixed effect & no & yes & no & no & yes & no \\
\hline region fixed effect & no & no & yes & no & no & yes \\
\hline Observations & 657 & 657 & 657 & 628 & 628 & 627 \\
\hline $\begin{array}{l}\text { R-squared } \\
\text { Hausman test } \\
\text { (p-value) }\end{array}$ & 0.39 & 0.661 & $\begin{array}{c}0.589 \\
291.18 \\
(0.000)\end{array}$ & 0.378 & 0.656 & 0.588 \\
\hline $\begin{array}{l}\text { Endogeneity test } \\
\text { (p-value) }\end{array}$ & & & & $\begin{array}{c}14.94 \\
(0.000)\end{array}$ & $\begin{array}{c}17.73 \\
(0.000)\end{array}$ & $\begin{array}{c}20.18 \\
(0.000)\end{array}$ \\
\hline
\end{tabular}

* significant at $10 \% ; * *$ significant at $5 \%$; ** significant at $1 \%$ 